\title{
High burden of hypovitaminosis $D$ among the children and adolescents in South Asia: A systematic review and meta-analysis
}

\author{
Mahbubul Hasan Siddiqee ( $\sim$ msiddiqee@bracu.ac.bd) \\ BRAC University https://orcid.org/0000-0001-7462-6477 \\ Badhan Bhattacharjee \\ BRAC University \\ Umme Ruman Siddiqi \\ Directorate General of Health Services, Dhaka-1212. \\ Mohammad Meshbahur Rahman \\ Biomedical Research Foundation, Dhaka - 1230
}

\section{Systematic Review}

Keywords: Vitamin D, deficiency, insufficiency, hypovitaminosis, prevalence, children, adolescents, South Asia, systematic review.

Posted Date: July 26th, 2021

DOI: https://doi.org/10.21203/rs.3.rs-747227/v1

License: (c) (i) This work is licensed under a Creative Commons Attribution 4.0 International License. Read Full License

Version of Record: A version of this preprint was published at Journal of Health, Population and Nutrition on March 17th, 2022. See the published version at https://doi.org/10.1186/s41043-022-00287-w. 


\section{Abstract}

Background: Vitamin D is vital for the growth and development of children. While deficiency and/or insufficiency of vitamin D among South Asian children are frequently reported in the literature, the lack of a meta-analysis has left its true extent poorly characterized. In this study, we aimed to conduct a systematic review and perform meta-analyses of the prevalence of hypovitaminosis D among the children of the South Asian countries.

Methods: Two major electronic search engines (PubMed and Scopus) and one database (Google scholar) were used; original studies, conducted among South Asian children and adolescents and published between $1^{\text {st }}$ January 2001 and $31^{\text {st }}$ December 2019. A random-effect meta-analysis was also performed to calculate the pooled prevalence of hypovitaminosis $D$ followed by subgroup analyses for countries and age-groups.

Results: After applying inclusion and exclusion criteria, a total of 41 studies with a total population size of 18,233 were finally selected. The overall prevalence of hypovitaminosis D was $61 \%[95 \% \mathrm{Cl}: 46 \%$ to $71 \%]$ with highly significant heterogeneity $\left(\mathrm{I}^{2}=99.72 \% ; \mathrm{p}=0.00\right)$. The average level of serum vitamin $D$ ranged from $5 \mathrm{ng} / \mathrm{mL}$ to $34 \mathrm{ng} / \mathrm{mL}$, with a weighted mean of $19.15 \mathrm{ng} / \mathrm{mL}$ (weighted standard deviation $11.59 \mathrm{ng} / \mathrm{mL}$ ). Country-wise analysis showed that hypovitaminosis D in Afghanistan was the highest [96.2\%; $95 \% \mathrm{Cl}: 91 \%$ to $99 \%$, followed by Pakistan [94\%; $95 \%$ Cl: $90 \%$ to $96 \%$ ], India [64\%; $95 \%$ Cl: $46 \%$ to $79 \%$ ], Bangladesh [35.48\%; $95 \%$ Cl: $32 \%$ to $39 \%$, Nepal [35\%; $95 \%$ Cl: $1 \%$ to $83 \%$.]and Sri Lanka [25\%; $95 \%$ Cl: $16 \%$ to $36 \%$ ]. Age-group analyses revealed that hypovitaminosis D was most prevalent among neonates [85\%; $95 \%$ Cl: $76 \%$ to $91 \%$, followed by school-going children [57\%; $95 \% \mathrm{Cl}: 33 \%$ to $80 \%]$, and pre-school children [55\%; $95 \% \mathrm{Cl}: 35 \%$ to $75 \%]$.

Conclusion: This study generates quantitative evidence and specific extent of hypovitaminosis D in the South Asian countries as a public health concern. Being the first systematic review for this region, results from this study will create awareness and will facilitate adopting mitigation strategies by the policymakers and the governments to address this problem.

\section{Background}

Vitamin D has a widespread role in the early development of children. The deficiency of this vitamin can often lead to suboptimal bone mass in infants, children, and adolescents. Nutritional rickets is a major bone-related disease that is caused by vitamin D deficiency $[1,2,3]$. According to the World Health Organisation (WHO), the peak incidence of rickets occurs among children and adolescents aged 2-11 years [4]. Besides rickets, vitamin D deficiency can also cause osteomalacia and other bone-related deformities among children $[3,4]$. It has been suggested that up to 200 genes could be regulated by the active form of vitamin $D(1,25$ dihydroxy vitamin $D)$, indicating its highly pleiotropic role [2,5]. Moreover, study reports suggested that the biological plausibility of vitamin D deficiency is also correlated with various kinds of chronic diseases like diabetes, cardiovascular disease, cancer, tuberculosis, etc $[2,5,6,7]$ So, a child suffering from vitamin D deficiency early in life becomes more susceptible to other kinds of diseases in the latter part of life.

Vitamin $D$ deficiency affects as many as 1 billion people globally and $50 \%$ of the world population suffers from vitamin $D$ insufficiency $[2,5]$. Worldwide, the extent of vitamin D deficiency among children and adolescents in both developed and developing countries is highly variable; prevalence as low as $5 \%$ to as high as $95 \%$ of the study population has been reported $[8,9,10]$.

A variety of factors have been highlighted as underlying variables to explain this large variance in serum vitamin $D$ status; besides nutrition, the extent of sunlight exposure is arguably the most important determinant $[2,11]$. Sunlight exposure eventually depends on some other factors like geographical location, people's skin colour, attitude towards sunlight exposure, clothing practice, etc. $[2,5,12]$. As such, understanding comparative variation within a region may reveal crucial clues regarding the potential determining factors of vitamin $\mathrm{D}$ deficiency or insufficiency (hypovitaminosis $\mathrm{D}$ ).

South Asia consists of eight countries - India, Bangladesh, Pakistan, Nepal, Bhutan, Maldives, Sri Lanka, and Afghanistan. Together, these South Asian countries occupy an area of 5.131 million square kilometers and have a population of about 1.8 billion $[13,14]$.

According to UNICEF, around 627 million children (< 18 years of age) live in South Asian countries and cover up approximately $36 \%$ of the total population (1.8 billion) [15]. Reported data indicates a high prevalence of nutritional rickets and other bone-related diseases, cardiovascular problems, diabetes, acute respiratory infections, tuberculosis, and other communicable diseases among South Asian children [4, 16-18]. All of these can be potentially linked to the high prevalence of hypovitaminosis $D$ in this region.

Despite the possibility of large-scale hypovitaminosis D in South Asia, we found only one systematic review (on Indian adolescent girls based on a very limited number of studies) in this region [19]. To address this knowledge gap, this study aims to conduct a systematic review and meta-analysis on the prevalence of hypovitaminosis D among South Asian children and adolescents.

\section{Methods}

Preferred Reporting Items for Systematic Reviews and Meta-Analyses (PRISMA-P 2015) have been followed as recommendations and guidelines for conducting this systematic review [20].

\section{Data source and Search strategy:}


PubMed and Scopus were the main databases, and Google Scholar was the main search engine, used in this analysis (to prevent personalized results, the search was conducted, after logging out of all Google accounts). Two researchers (BB and MMR) independently investigated these three datasets (from 26 October 2019 until 26 January 2020) to find out the studies conducted from 2001 until the search date. The details about search strategy, original MeSH terms, and alternative terms are available in [Additional file: Table S1].

The searches were carried out in English. The corresponding author's personal profiles available online (Google Scholar, ResearchGate, ORCID, and organizational profile), as well as the reference list of our selected studies, were further explored to maximize the search efficiency.

To ensure the inclusion of grey literature, we went through online archives of newspapers that have been published in English among South Asian countries as; The Hindu, The Indian Express, New Age, The Nation, Daily Bhutan, Maldives Times, Himalayan Times, Sunday Observer, etc. We also explored governments' reports and published abstracts (in electronic media) as relevant sources from the conference held in South Asian countries

\section{Study selection criteria:}

Clinical Practice Guideline of the Endocrine Society currently defines vitamin D deficiency, insufficiency, and sufficiency as a serum level of vitamin D $<12 \mathrm{ng} / \mathrm{mL}(<30 \mathrm{nmol} / \mathrm{L}),<20 \mathrm{ng} / \mathrm{mL}(<50 \mathrm{nmol} / \mathrm{L})$ and $>20 \mathrm{ng} / \mathrm{mL}(>50 \mathrm{nmol} / \mathrm{L})$ respectively [21, 22]. In this study, we defined hypovitaminosis D (vitamin D deficiency or insufficiency) as per current guidelines (cut off $<20 \mathrm{ng} / \mathrm{mL}$ ). Studies were selected if serum levels of vitamin $\mathrm{D}<20 \mathrm{ng} / \mathrm{mL}$ in South-Asian children and adolescents were reported. The inclusion criteria were: study conducted in South-Asian countries from January ${ }^{\text {st }}$, 2001 to December $31^{\text {st }}, 2019$; study conducted in the hospital setting or community setting among apparently healthy children and adolescents who were up to 18 years of age, children and adolescents with a minor illness whose physical conditions were not correlated with any chronic diseases or coexisting morbidity [e.g., chronic kidney disease, cardiovascular disease, diabetes, rheumatoid arthritis, cancer, tuberculosis, body aches and pain, proximal muscle weakness, osteoporosis, etc.]. Among different study designs, cross-sectional, longitudinal, case-control (only control group), randomized clinical trial (baseline and placebo data) were included.

Studies were excluded if they had a sample size less than 50 [19]; reported vitamin D levels after some form of intervention or supplementation; conducted on other groups of the population rather than children and adolescents such as pregnant women, adults, and elderly; the reported prevalence of hypovitaminosis D associated to any kind of chronic diseases or disease related to any coexisting morbidity; conducted on a special group of children and adolescents such as physically or mentally challenged; did not mention the prevalence of deficiency and mean level of serum vitamin D; letter to the editor, review article, editorial article; Studies which satisfied selection criteria but were not obtainable from the authors after request were also excluded.

To handle the references and prevent duplications, Mendeley Desktop Program (version 1.19.4) was used. After eliminating duplicates, two researchers (MHS and URH) independently reviewed all papers before final selection for meta-analysis. Any disagreements were resolved through discussion with co-authors.

\section{Data extraction:}

To extract data from all eligible studies, a standardized form was used. The following information has been collected for each study: publication details [e.g., first author, publication date, journal name, and publisher]; research setting, design and population [e.g., country, study area, study design, method of measurements, and sample size]; participants' characteristics [e.g., gender, age, and socio-economic status] and major findings [mean level of serum vitamin $\mathrm{D}$ and prevalence percentage of hypovitaminosis $\mathrm{D}]$.

In our selected studies, where mean values of serum vitamin D were given in nanomol per unit liter (nmol/L), we converted to nanogram per milliliter $(\mathrm{ng} / \mathrm{mL}$ ) by dividing with 2.5 (according to the international unit conversion system) to maintain uniformity of data.

\section{Evaluation of study quality}

We used a checklist of 10 parameters validated by Hoy et al (2012). to assess the risk of bias (as weak, moderate, and high) for the selected papers [23]. As per the checklist, studies with a score of 0-3 are considered as low risk, a score within 4-6 is moderate risk, and studies with a score of 7-9 are considered as high risk of bias.

\section{Statistical analysis}

The mean value of the serum vitamin $D$ and the prevalence of hypovitaminosis $D$ in South Asian children and adolescents are regarded as summary measurements. The weighted mean level of serum vitamin D was calculated by using Microsoft Excel (version 2016). A random-effect meta-analysis was used to obtain the weighted pooled prevalence with a confidence interval of $95 \%$. Cochran's Q test and the $I^{2}$ statistics were used to assess heterogeneity [24]. Substantial heterogeneity was suggested with an $I^{2}$ of more than $75 \%$ [25]. The analyses were performed using the metaprop, metabias, metafunnel commands by Stata version 15 (Stata Corp, College Station, TX)

\section{Result}


A total of 1903 articles were retrieved from different databases by using our search strategy. Among these 1903 studies, 1862 articles were excluded because they did not fulfill our inclusion criteria. A total of 41 articles, finally qualified for meta-analyses. Figure 1 shows the selection process used in this study.

Most of the studies were community-based (24 out of 41). The study design was cross-sectional for most of the studies (30 out of 41 ). Several kinds of measurement methods were used to determine the serum level of vitamin D. Among these Radioimmunoassay (RIA; 14 out of 41 ) Chemiluminescent Immunoassay (CLIA; 9 out of 41), and Enzyme-linked Immunosorbent assay (ELISA; 4 out of 41 ) were mostly used. Only two studies did not mention their procedure of vitamin D estimation [49,64]. Among the selected studies, more than half did not mention demographic area (25 out of 41 ), and socio-economic condition (26 out of 41 ) for the study population. Table 1 shows the summary outlining the characteristics of selected articles.

Studies selected in this systematic review consisted of 18233 participants. While most of these studies reported serum vitamin D levels of children up to 18 years of age, two studies included participants of up to 20 years $[27,56]$. The overall pooled prevalence of hypovitaminosis $\mathrm{D}$ was $61 \%[95 \% \mathrm{Cl}$ : $46 \%$ to $71 \%$ ] with a high degree of heterogeneity $\left(I^{2}=99.72 \% ; p=0.00\right)$. Figure 2 shows the overall forest plot about the prevalence of hypovitaminosis D in South Asia.

Prevalence of hypovitaminosis $\mathrm{D}$ and the average level of serum vitamin $\mathrm{D}$ was mentioned in all studies; prevalence ranged from $8 \%$ to $96 \%$ and average ranged from $5 \mathrm{ng} / \mathrm{mL}$ to $34 \mathrm{ng} / \mathrm{mL}$ (for the individual studies). The weighted mean level of serum vitamin $\mathrm{D}$ was $15.48 \mathrm{ng} / \mathrm{mL}$ and the weighted standard deviation (weighted SD) was $7.49 \mathrm{ng} / \mathrm{mL}$.

Effect of geographical location on the prevalence of hypovitaminosis D:

We found studies following our inclusion criteria from 6 out of 8 South Asian countries. No studies were found from Bhutan and Maldives. A summary table shows the country-wise result (Table 2). We found that Afghanistan has the highest and Sri Lanka has the lowest prevalence of hypovitaminosis D in South Asia. The Forest plot shows the country-wise prevalence of hypovitaminosis D (Figure 3). A bar diagram shows the weighted mean level of vitamin D among South Asian children. (Additional file: Figure S1).

India:

We found thirty-one studies from India with a total of 14497 participants [26-56]. The weighted mean level of hypovitaminosis D for study participants was $13.40 \mathrm{ng} / \mathrm{mL}$ (SD $6.61 \mathrm{ng} / \mathrm{mL}$ ) and random effect meta-analysis showed that the pooled prevalence of hypovitaminosis D was $64 \%$ [95\% Cl: $46 \%$ to $79 \%$ ] with a high level of heterogeneity $\left(I^{2}=99.75 \% ; p=0.00\right)$.

\section{Nepal:}

There were three studies from Nepal which consisted of 1746 participants [57-59]. The random effect meta-analysis pointed that the prevalence of hypovitaminosis D was $35 \%$ [95\% Cl: $1 \%$ to $83 \%$.] and the weighted mean level of serum vitamin D for study participants was $25.96 \mathrm{ng} / \mathrm{mL}$ (weighted SD $7.29 \mathrm{ng} / \mathrm{mL})$

\section{Sri Lanka:}

In Sri Lanka, there were three studies comprised of 693 participants [60-62]. The weighted mean level of serum vitamin D for study participants was $27.34 \mathrm{ng} / \mathrm{mL}$ (weighted SD $9.54 \mathrm{ng} / \mathrm{mL}$ ) and random effect meta-analysis showed that the weighted pooled prevalence of hypovitaminosis D was $25 \%$ [95\% Cl: $16 \%$ to $36 \%]$.

\section{Pakistan:}

We found two studies from Pakistan [63-64] which together consisted of 277 participants and the random effect meta-analysis showed that $94 \%$ [95\% Cl: $90 \%$ to $96 \%$ ] of participants were hypovitaminosis D with $11.78 \mathrm{ng} / \mathrm{mL}$ weighted mean level of serum vitamin D (weighted SD $7.99 \mathrm{ng} / \mathrm{mL}$ ).

\section{Bangladesh:}

There was only one study from Bangladesh [65] which included 913 participants with $21.86 \mathrm{ng} / \mathrm{mL}$ mean level of serum vitamin D and $35.48 \%$ [95\% Cl: $32 \%$ to $39 \%$ ] of them had hypovitaminosis D.

\section{Afghanistan:}

We found a single study from Afghanistan [66] which comprised 107 participants and the study result revealed $96.2 \%$ [95\% Cl: $91 \%$ to $99 \%$ ] of them had hypovitaminosis $\mathrm{D}$ with $5 \mathrm{ng} / \mathrm{mL}$ mean level of serum vitamin $\mathrm{D}$.

\section{Effect of gender on prevalence of hypovitaminosis D:}


All of the studies we found were conducted either on both genders or only among female children and adolescents. A summary table shows genderwise results (Table 3). We categorized this section into two parts. Studies which included participants from both gender and studies which consider only female children as their participants. Overall study result shows high degree of heterogeneity $\left(I^{2}=>99 \% ; p=0.00\right)$. Figure 4 shows the gender-wise forest plot.

\section{Studies included participants from both gender:}

We found 36 out of 41 studies which included participants from both genders and among these studies, 26 studies were conducted in India, 2 studies in Pakistan, 3 studies in Nepal, 3 studies in Sri Lanka, and one study from Bangladesh and Afghanistan each [26-30, 33-37, 39-41, 43, 45-66]. Together, these studies comprised of 16,434 participants, and a random effect meta-analysis indicated that $58 \%$ [ $95 \%$ Cl: $43 \%$ to $73 \%$ ] of study participants were hypovitaminosis $D$ with a high degree of heterogeneity $\left(\mathrm{I}^{2}=98.72 \%\right.$; $\left.\mathrm{p}=0.00\right)$ The mean level of serum vitamin $\mathrm{D}$ ranged from $5 \mathrm{ng} / \mathrm{mL}$ to $34 \mathrm{ng} / \mathrm{mL}$ (for the individual studies) among study participants.

\section{Studies included only female participants:}

We found 5 out of 41 studies that included only female participants and all of these studies were conducted in India [31, 32, 38, 42, 44]. These studies together comprised 1799 participants and random-effect meta-analysis demonstrated that 76\% [95\% Cl: 46\% to 96\%] of study participants had hypovitaminosis $D$ with a high number of heterogeneity $\left(I^{2}=99.37 \% ; p=0.00\right)$. The mean level of serum vitamin $D$ among study participants ranged from 9 to $24 \mathrm{ng} / \mathrm{mL}$.

\section{Prevalence of hypovitaminosis D for different age groups:}

In this section, we categorized study participants into four groups according to their age and these are 1 month (neonates), 1 month to 5 years (infants and preschool children), 6 to 18 years (school children), and others (<20 years). A summary table shows the age-wise result (Table 4$)$. We found out that, in South Asia, infants and preschool children have the lowest and neonates have the highest prevalence of hypovitaminosis D. Overall study result shows high degree of heterogeneity $\left(I^{2}=>84 \% ; p=0.00\right)$. Forest plot with further detail is available in; Figure 5 .

\section{School Children (6-18 years):}

We identified 17 out of 41 studies with individuals aged 6 to 18 years old. Only one of these studies was conducted in Nepal and the rest were conducted in India [26, 28-34, 36-44]. Together, these studies consisted of 12709 participants and random-effect meta-analysis showed that 57\% [95\% Cl: $33 \%$ to $80 \%$ ] of study participants had hypovitaminosis $D$ with a high degree of heterogeneity $\left(l^{2}=99.85 \%\right)$. The mean level of serum vitamin $D$ among study participants ranged from $6.3 \mathrm{ng} / \mathrm{mL}$ to $26.52 \mathrm{ng} / \mathrm{mL}$ (for the individual studies).

\section{Infants and Preschool Children (1 month - 5 years):}

There were 14 out of 41 studies which included participants who were 1 month to 5 years of age and among these studies 7 were conducted in India, 3 in Sri Lanka, 2 in Nepal, and one study was conducted in Bangladesh and Afghanistan each [45, 47, 48, 51, 53, 54, 57-62, 65, 66]. Together, these studies consisted of 4324 participants with $5 \mathrm{ng} / \mathrm{mL}$ to $33.71 \mathrm{ng} / \mathrm{mL}$ mean serum level of vitamin D. Random-effect meta-analysis showed that $55 \%$ [95\% Cl: $35 \%$ to $75 \%$ ] of study participants had hypovitaminosis D with a high degree of heterogeneity $\left(I^{2}=99.47 \% ; p=0.00\right)$.

\section{Neonates (1 month):}

We found 6 out of 41 studies which included participants who were up to 1 month in age. Among, these studies 4 were conducted in India and 2 in Pakistan [46, 49, 52, 55, 63, 64]. Together, these studies consisted of 763 participants and random-effect meta-analysis revealed that $85 \%$ [95\% Cl: $76 \%$ to $91 \%$ ] of study participants had hypovitaminosis $D$ with a high degree of heterogeneity $\left(I^{2}=84.82 \% ; p=0.00\right)$. The mean level of serum vitamin $D$ ranged from $6 \mathrm{ng} / \mathrm{mL}$ to $20 \mathrm{ng} / \mathrm{mL}$ among study participants.

\section{Others:}

In this group participants' age range was < 20 years. In total, we found 4 studies in this section, and all of these were conducted in India [27, 35, 50, 56]. These studies together consisted of 437 participants and random-effect meta-analysis showed that $57 \%$ [ $95 \%$ Cl: $35 \%$ to $77 \%$ ] of study participants had hypovitaminosis $D$ with a high degree of heterogeneity $\left(I^{2}=95.20 \% ; p=0.00\right)$. The average vitamin $D$ level of study participants ranged from 14 $\mathrm{ng} / \mathrm{mL}$ to $30 \mathrm{ng} / \mathrm{mL}$.

\section{Quality assessment:}

Among these selected studies no study was found with a high risk of bias, 15 studies have a moderate risk of bias and the rest contained a low risk of bias. The risk of Bias for selected studies is available in [Additional file: Table S2].

\section{Publication bias:}


The presence of asymmetry and publication bias was indicated by the funnel plot. The Eggers test was found to be statistically insignificant, implying that small-study effects were not present. $(p=0.74)$. The funnel plot is available in [Additional file: Figure S2].

\section{Discussion}

This study reveals that approximately 6 out of 10 South Asian children and adolescents (up to 18 years) could be affected with hypovitaminosis D (Figure 2). Comparison of this hypovitaminosis D to the other parts of the world implies that this problem might be worse in South Asia compared to Africa (around 34\%; taking $<20 \mathrm{ng} / \mathrm{mL}$ cut-off) [67]. We assume that hypovitaminosis D may be co-related to the high prevalence of some childhood health problems in this area. Indeed, this is supported by several reports suggesting a high burden of diseases that are associated with vitamin $D$ deficiency like tuberculosis, obesity and overweight, type 1 diabetes, etc. among South Asian children and adolescents [4, 16-18, 68-71].

While high hypovitaminosis D was the highlight of this study, we also found significant amounts of heterogeneity in the overall result $\left(I^{2}=99.72 \%\right)$ and it can be assumed that geography might be acting as one of the significant variables. Because, vitamin D is synthesized naturally in our body when UVB from sunlight penetrates our skin and undergoes some physiological processes $[2,5]$. This is likely since people living in tropical areas are exposed to more sunlight than those living in subtropical regions [2, 5]. Among the South Asian countries, Pakistan and Afghanistan are situated in a subtropical area, while Sri Lanka is situated in a tropical area [72]. In our study, we also found that Pakistan and Afghanistan had the highest prevalence of hypovitaminosis D in South Asia; $94 \%$ (nation-wide average of serum vitamin D $11.78 \mathrm{ng} / \mathrm{mL}$ ) and $96 \%$ (nation-wide average of serum vitamin D $5 \mathrm{ng} / \mathrm{mL}$ ) respectively. On the contrary, Sri Lanka has the lowest level of hypovitaminosis D in South Asia; $25 \%$ (nationwide average of serum vitamin D $27.34 \mathrm{ng} / \mathrm{mL}$ ). Our hypothesis is further strengthened by reports from other tropical and subtropical countries. For example, Brazil is located in a tropical region and according to published literature, only $28 \%$ of the Brazilian population had hypovitaminosis $\mathrm{D}$, while Qatar, a sub-tropical country had a high prevalence (90\%) of hypovitaminosis D $[73,74]$. However, it must be noted that besides geographical variation, other variables could be affecting the inter-country variations.

Among the factors influencing the production of vitamin D, age, gender, and diet are notable [2, 5]. In our study, the age-wise analysis revealed that the prevalence of hypovitaminosis D is more among neonates (85\%) than preschool (55\%) and school-going children (57\%) [Figure 5]. This may be associated with the high prevalence of vitamin D insufficiency (65\%) among South Asian pregnant women which we have shown in one of our recent studies [75].

Most of the studies in South Asia enrolled participants from both genders. We did not find any study in South Asia that was conducted on males only. We found five studies that were conducted among females. Gender-wise comparison suggested that the studies that considered only females as participants showed a higher prevalence of hypovitaminosis D (76\%; $95 \% \mathrm{Cl}$ : $46 \%$ to $96 \%$ ) compared to those that considered participants from both genders (58\%; $95 \% \mathrm{Cl}: 43 \%$ to $73 \%$ ) [Figure 4]. This could be suggestive of the fact that female children in South Asia could be more affected with hypovitaminosis D compared to young males. This may be associated with cultural aspects and clothing practices of South Asian where females practice heavier clothing (traditional and religious full-body covering dresses like burqa, hijab, shari, salwar, kurta, etc). A recent media report also pointed that these practices have increased dramatically in this region over the past three decades [76]. However, we also argue that early marriage (which concerning early pregnancy), poor education, and insufficient decision-making ability may have some combined effects resulting in such a high prevalence of hypovitaminosis D among South Asian girls. In this regard, lack of recommended dietary intake, early marriage, and lack of higher education among girls has been reported in this region $[77,78]$.

Furthermore, skin complexion may be another factor for such a high prevalence of hypovitaminosis $D$ in this region. According to the Fitzpatrick scale, South Asians are quite darker in comparison to Europeans [79]. A large observational data suggested that the prevalence of hypovitaminosis D (taking $<20 \mathrm{ng} / \mathrm{mL}$ cut off) is $40 \%$ among Europeans [80] which is much lower in comparison to what we have seen in this study for South Asia.

The high burden of hypovitaminosis D among South Asian children is a public health concern that should be addressed as an emergency. Some researchers also proposed that deficiency of vitamin D should be treated as a pandemic in progress [80]. In this regard, a more recent study reported that vitamin D deficiency is also related to 'cytokine storm' (dramatic immune system overreaction) which causes COVID 19 patients more vulnerable [81]. However, we also proposed that further research is needed to check if our findings can be applied to a wider group of general populations.

Despite the high prevalence of hypovitaminosis D among South Asian children and adolescents, we did not find any national-level nutritional guidelines or policies for vitamin D except in India [82]. For the prevention of hypovitaminosis D among children and adolescents, China, Japan, and South Korea have similar guidelines [83, 84]. Furthermore, supplementation and food fortification programs have been proved to be successful in Europe to reduce hypovitaminosis D [85]. Moreover, some other challenges need to be addressed in South Asia. A negative attitude towards sunlight exposure can be a big challenge. It has been reported that Indian and Pakistani students had a lack of knowledge about vitamin D and a negative attitude towards sunlight exposure $[86,87]$. This lack of knowledge, along with a negative attitude, could be a key factor behind staying away from sunlight which can lead to hypovitaminosis D. Therefore, keeping the socio-cultural aspects of the individual countries (e.g., clothing practice, skin complexion, and economic status) in consideration, awareness campaigns about the relationship between sunlight exposure as a source of vitamin $\mathrm{D}$ can be emphasized. Furthermore, active measures should be taken to expand the number of diagnostic tests for detecting the serum vitamin $D$ level. To achieve this, increasing the number of tests centers, reducing the cost of testing the serum level of vitamin D by offering subsidies can also be considered by the governments in the South Asian region. 
To the best of our knowledge, this is the first systematic review and meta-analysis to highlight the prevalence of hypovitaminosis D in South Asian children. But this study also has few limitations. Above 75\% of our selected studies (31 out of 41) were conducted among Indian children. In this regard, the population of India is also disproportionately higher compared to the other South Asian countries. We did not find any studies from Maldives and Bhutan. So, we could not calculate the prevalence of hypovitaminosis D and the weighted mean level of serum vitamin D for these countries. Moreover, more than $60 \%$ of our selected studies did not mention demographic area (urban vs rural) and socioeconomic status (high income vs low income) for their study populations. Therefore, we were unable to find any correlations between hypovitaminosis $D$ and these factors. Furthermore, multiple different methods were used in different studies (Table 1) to assay the serum level of vitamin D, which might have introduced some degree of assay bias. However, this limitation is inherent for studies like ours and was indeed unavoidable. Another limitation is that, since, the definition of children and adolescents were not uniform [88], and that many of our selected studies did not provide age-wise data, we could not perform the subgroup analysis for children and adolescents as separate age groups. Furthermore, vitamin D assessments are often expensive for South Asian children and adolescents due to their poor economic circumstances. So, it is possible that the children and adolescents who were enrolled in at least some studies or who participated in a study or a trial that included assessment of vitamin D were indeed suspected of deficiency/insufficiency of this vitamin. We assume that this is another inherent yet unavoidable limitation of our study. Therefore, we recommend that the readers should exercise caution before generalizing the extent of hypovitaminosis D in South Asia.

\section{Conclusions}

Out study unveiled that around six out of ten South Asian children and adolescents could be suffering from hypovitaminosis D. These findings have generated evidence of the actual population-level data that underscores the urgency of prioritizing the mitigation strategies. The sub-group analyses have resulted in several hypotheses to explain the observed heterogeneity of hypovitaminosis D among different countries, age-groups, and genders. While this systematic review focused on South Asian children, the knowledge and insight generated from this study can be applied to other regions and countries with comparable geographic and socio-cultural aspects.

\section{Abbreviations}

used in Table 1

RCT $=$ Randomized Control Trial, CC = Case Control, CS = Cross Sectional, CIA = Commercial Immunoassay, RIA = Radio Immune assay, ELISA = Enzyme Linked Immune Sorbent Assay, CLIA = Chemiluminescence immunoassay, CMIA = Chemiluminescent micro particle immune assay, IRMA = Immunoradiometric immunoassay, HPLC = High performance liquid chromatography, LCMS = Liquid chromatography tandem mass spectroscopy, EIA = Enzyme Immunoassay, ECLIA = Electrochemiluminescence Immunoassay, NM = Not mention, $y=$ Year $m=$ Month, $d=d a y$

\section{Declarations}

\section{Acknowledgments:}

We are thankful to Mohammed Tanveer Hussain for his efforts in checking the grammatical aspects of the manuscript.

\section{Authors Contribution:}

MHS and URS conceptualize the idea and supervise the overall project. MHS and BB designed this study. BB played a major role in searching the literature, data compilation, and preparing the first draft of the manuscript. MHS and URS reviewed the selected literature for analysis. MHS and BB prepared the bias table for quality assessment. MMR played a major role in data analysis. MHS, URS and MMR critically revised the manuscript.

\section{Funding:}

This study did not receive any funding from public, commercial or non-profit organizations.

\section{Availability of data and materials:}

Only aggregated summaries of the data are provided in this manuscript. However, all data generated in this study can be made publicly available on request. Please contact the corresponding author for any kind of data request.

\section{Ethics approval and consent to participate:}

Not Applicable.

\section{Consent for publication:}

Not Applicable.

\section{Competing interests:}


The authors declare that they have no competing interests.

\section{Author information}

1 School of Data and Sciences, BRAC University, Dhaka-1212, Bangladesh. 2 Research and Development Wing, Red and White Innovations, Dhaka1216, Bangladesh.3Communicable Disease Control Unit, Directorate General of Health Services, Dhaka-1212, Bangladesh. 4Biomedical Research Foundation, Dhaka-1230, Bangladesh.

\section{References}

1. Fiscaletti M, Stewart P, Munns CF. The importance of vitamin D in maternal and child health: a global perspective. Public Health Rev. 2017; 38(1):1-7. doi: 10.1186/s40985-017-0066-3.

2. Nair R, Maseeh A. Vitamin D: The sunshine vitamin. J Pharmacol Pharmacother. 2012; 3(2):118-126. doi:10.4103/0976-500X.95506

3. Huh SY, Gordon CM. Vitamin D deficiency in children and adolescents: Epidemiology, impact and treatment. Rev Endocr Metab Disord. 2008; 9(2):161-170. doi: 10.1007/s11154-007-9072-y

4. World Health Organization. Nutritional Rickets: A Review of Disease Burden, Causes, Diagnosis, Prevention and Treatment. 2019; Page; 8-25, ISBN: 9789241516587.

5. Holick MF. Vitamin D deficiency. N Engl J Med. 2007; 357(3):266-81. doi: 10.1056/NEJMra070553.

6. Muscogiuri G, Altieri B, Annweiler C, Balercia G, Pal HB, Boucher BJ, Cannell JJ, Foresta C et al Vitamin D and chronic diseases: the current state of the art. Arch Toxicol. 2017; 91(1):97-107. doi: 10.1007/s00204-016-1804-x.

7. Huang SJ, Wang XH, Liu ZD, et al. Vitamin D deficiency and the risk of tuberculosis: A meta-analysis. Drug Des Devel Ther 2017; 11:91-102. doi:10.2147/DDDT.S79870.

8. Palacios C, Gonzalez L. Is Vitamin D deficiency a major global public health problem? The Journal of steroid biochemistry and molecular biology. 2014; 144:138-45. doi: 10.1016/j.jsbmb.2013.11.003

9. Zhu Z, Zhan J, Shao J, Chen W, Chen L, Li W et al. High prevalence of vitamin D deficiency among children aged 1 month to 16 years in Hangzhou, China. BMC Public Health. 2012;12(1): 1-7.doi: 10.1186/1471-2458-12-126

10. Halicioglu O, Aksit S, Koc F, Akman SA, Albudak E, Yaprak I et al. Vitamin D deficiency in pregnant women and their neonates in spring time in western Turkey. Paediatr Perinat Epidemiol. 2012;26(1):53-60.

11. O'Sullivan F, Raftery T, van Weele M, van Geffen J, McNamara D, O'Morain C et al. Sunshine is an Important Determinant of Vitamin D Status Even Among High-dose Supplement Users: Secondary Analysis of a Randomized Controlled Trial in Crohn's Disease Patients. Photochem Photobiol. 2019; 95(4):1060-7. doi: 10.1111/php.13086.

12. Yeum KJ, Song BC, Joo NS. Impact of geographic location on vitamin D status and bone mineral density. Int J Environ Res and Public Health. 2016; 13(2):184. doi: 10.3390/ijerph13020184

13. The World Bank [Internet]. South Asia. Available from: <https://data.worldbank.org/region/south-asia> Accessed December 18, 2020.

14. Sivaramamurti, Calambur, Alexeeva, Nina Nikolaevna, Yefremov, Yury Konstantinovich et al. "South Asia". Encyclopedia Britannica, 1 Sep. 2020, <https://www.britannica.com/place/South-Asia>. Accessed 7 January 2021.

15. UNICEF [Internet] South Asia. Children in South Asia. Available from: <https://www.unicef.org/rosa/children-south-asia> Accessed November $2,2020$.

16. Prasad DS, Kabir Z, Dash AK, Das BC. Childhood cardiovascular risk factors in South Asians: A cause of concern for adult cardiovascular disease epidemic. Ann Pediatr Cardiol. 2011; 4(2):166-171. doi:10.4103/0974-2069.84663

17. Siegel KR, Patel SA, Ali MK. Non-communicable diseases in South Asia: contemporary perspectives. Br Med Bull. 2014; 111(1):31-44. doi: 10.1093/bmb/ldu018.

18. Zaidi AKM, Awasthi S, DeSilva HJ. Burden of infectious diseases in South Asia. Br Med J. 2004; 328(7443):811-815. doi:10.1136/bmj.328.7443.811

19. Jeyakumar A, Shinde V. A systematic review and meta-analysis of prevalence of vitamin D deficiency among adolescent girls in selected Indian states. Nutr Health. 2019; 25(1):61-70. doi:10.1177/0260106018805360

Page $8 / 20$ 
20. Moher D, Shamseer L, Clarke M, et al. Preferred reporting items for systematic review and meta-analysis protocols (PRISMA-P) 2015 statement. Syst Rev. 2015; 4:1. doi: https://doi.org/10.1186/2046-4053-4-1

21. Giustina A, Adler RA, Binkley N, Bouillon R, Ebeling PR, Lazaretti-Castro M, Marcocci C, Rizzoli R, Sempos CT, Bilezikian JP. Controversies in Vitamin D: Summary Statement From an International Conference. J Clin Endocrinol Metab. 2019;104(2): 234-240.doi:10.1210/jc.2018-01414

22. Ahmed F, Khosravi-Boroujeni H, Khan MR, Roy AK, Raqib R. Prevalence and Predictors of Vitamin D Deficiency and Insufficiency among Pregnant Rural Women in Bangladesh. Nutrients. 2021;13(2):449. doi: 10.3390/nu13020449.

23. Hoy D, Brooks P, Woolf A, et al. Assessing risk of bias in prevalence studies: Modification of an existing tool and evidence of interrater agreement. J Clin Epidemiol. 2012; 65(9):934-939. doi: 10.1016/j.jclinepi.2011.11.014.

24. Chowdhury MZI, Rahman M, Akter T, et al. Hypertension prevalence and its trend in Bangladesh: evidence from a systematic review and metaanalysis. Clin Hypertens. 2020; 26(1):10. doi:10.1186/s40885-020-00143-1.

25. Higgins JPT, Thompson SG, Deeks JJ, Altman DG. Measuring inconsistency in meta-analyses. Br Med J. 2003; 327(7414):557-560. doi:10.1136/bmj.327.7414.557.

26. Marwaha RK, Tandon N, Reddy DRHK, et al. Vitamin D and bone mineral density status of healthy schoolchildren in northern India. Am J Clin Nutr. 2005; 82(2):477-482. doi:10.1093/ajcn/82.2.477

27. Sahu M, Bhatia V, Aggarwal A, et al. Vitamin D deficiency in rural girls and pregnant women despite abundant sunshine in northern India. Clin Endocrinol. 2009; 70(5):680-684. doi:10.1111/j.1365-2265.2008.03360.x

28. Mandlik R, Kajale N, Ekbote V, et al. Determinants of Vitamin D status in Indian school-children. Indian J Endocrinol Metab. 2018 ; $22(2): 244$. doi: 10.4103/ijem.ijem_622_17

29. Kapil U, Pandey R, Goswami R, et al. Prevalence of Vitamin D deficiency and associated risk factors among children residing at high altitude in Shimla district, Himachal Pradesh, India. Indian J Endocrinol Metab. 2017; 21(1):178-183. doi:10.4103/2230-8210.196031

30. Basu S, Gupta R, Mitra M, Ghosh A. Prevalence of Vitamin D Deficiency in a Pediatric Hospital of Eastern India. Indian J Clin Biochem. 2015; 30(2):167-173. doi: 10.1007/s12291-014-0428-2

31. Puri S, Marwaha RK, Agarwal N, et al. Vitamin D status of apparently healthy schoolgirls from two different socioeconomic strata in Delhi: Relation to nutrition and lifestyle. Br J Nutr. 2008; 99(4):876-882. doi: 10.1017/S0007114507831758

32. Kadam NS, Chiplonkar SA, Khadilkar A V., Fischer PR, Hanumante NM, Khadilkar V V. Modifiable factors associated with low bone mineral content in underprivileged premenarchal Indian girls. J Pediatr Endocrinol Metab. 2011; 24(11-12):975-981. doi:10.1515/JPEM.2011.405.

33. Khadgawat R, Marwaha RK, Garg MK, et al. Impact of vitamin D fortified milk supplementation on vitamin D status of healthy school children aged 10-14 years. Osteoporos Int. 2013; 24(8):2335-2343. doi: 10.1007/s00198-013-2306-9

34. Chaudhuri JR, Mridula KR, Rathnakishore C, Balaraju B, Bandaru VS. Association of 25-hydroxyVitamin D deficiency in pediatric epileptic patients. Iran J Child Neurol. 2017; 11(2):48. PMID: 28698728

35. Sharawat IK, Dawman L. Bone mineral density and its correlation with Vitamin D status in healthy school-going children of Western India. Arch Osteoporos. 2019; 14(1):9-14. doi: 10.1007/s11657-019-0568-3

36. Marwaha RK, Yenamandra VK, Sreenivas V, et al. Regional and seasonal variations in ultraviolet B irradiation and Vitamin D synthesis in India. Osteoporos Int. 2016; 27(4):1611-1617. doi:10.1007/s00198-015-3427-0

37. Sarma D, Saikia UK, Baro A. Vitamin D status of school children in and around Guwahati. Indian J Endocrinol Metab. 2019 23(1):

81.doi:10.4103/ijem.IJEM_552_18

38. Sanwalka N, Khadilkar A, Chiplonkar S, Khatod K, Phadke N, Khadilkar V. Vitamin D receptor gene polymorphisms and bone mass indices in post-menarchal Indian adolescent girls. J Bone Miner Metab. 2013; 31(1):108-115. doi: 10.1007/s00774-012-0390-0

39. Mandlik R, Khadilkar A, Kajale N, Ekbote V, Patwardhan V, Mistry S, Khadilkar V, Chiplonkar S. Response of serum 25 (OH) D to Vitamin D and calcium supplementation in school-children from a semi-rural setting in India. J Steroid Biochem Mol Biol. 2018; 180:35-40. doi:

10.1016/j.jsbmb.2017.12.003

40. Borkar V V., Devidayal VS, Bhalla AK. Low levels of Vitamin D in North Indian children with newly diagnosed type 1 diabetes. Pediatr Diabetes. 2010; 11(5):345-350. doi:10.1111/j.1399-5448.2009.00589.x 
41. Garg MK, Tandon N, Marwaha RK, Menon AS, Mahalle N. The relationship between serum 25-hydroxy vitamin D, parathormone and bone mineral density in Indian population. Clin Endocrino (Oxf). 2014; (17):41-46. doi:10.1111/cen.12248

42. Khadilkar A, Kadam N, Chiplonkar S, Fischer PR, Khadilkar V. School-based calcium-Vitamin D with micronutrient supplementation enhances bone mass in underprivileged Indian premenarchal girls. Bone. 2012; 51(1):1-7. doi: 10.1016/j.bone.2012.03.029

43. Patel P, Zulf Mughal M, Patel P, et al. Dietary calcium intake influences the relationship between serum 25-hydroxyVitamin D3 (250HD) concentration and parathyroid hormone (PTH) concentration. Arch Dis Child. 2016; 101(4):316-319. doi: 10.1136/archdischild-2015-308985

44. Marwaha RK, Garg MK, Gupta S, et al. Association of insulin-like growth factor-1 and IGF binding protein-3 with 25-hydroxy Vitamin D in prepubertal and adolescent Indian girls. J Pediatr Endocrinol Metab. 2018; 31(3):289-295. doi: 10.1515/jpem-2017-0275

45. Prasad S, Rana RK, Seth R, Mauskar A V. A hospital-based study to establish the correlation between recurrent wheeze and Vitamin D deficiency among children of age group less than 3 years in Indian scenario. J Clin Diagnostic Res. 2016; 10(2):SC18-SC21.

doi:10.7860/JCDR/2016/17318.7287.

46. Agarwal R, Virmani D, Jaipal ML, et al. Vitamin D status of low-birth-weight infants in Delhi: A comparative study. J Trop Pediatr. 2012; 58(6):446-450. doi:10.1093/tropej/fms013.

47. Wayse V, Yousafzai A, Mogale K, Filteau S. Association of subclinical Vitamin D deficiency with severe acute lower respiratory infection in Indian children under 5 y. Eur J Clin Nutr. 2004; 58(4):563-567. doi: 10.1038/sj.ejcn.1601845

48. Filteau S, Rehman AM, Yousafzai A, et al. Associations of Vitamin D status, bone health and anthropometry, with gross motor development and performance of school-aged Indian children who were born at term with low birth weight. BMJ Open. 2016; 6(1). doi: 10.1136/bmjopen-2015009268

49. Gupta T, Wahi S, Gupta N, Arora S, Gupta S, Bhatia P. Correlation of Vitamin D Levels in Term Normotensive and Pre-eclamptic Patients in Labor. J Obstet Gynecol India. 2016; 66(3):154-159. doi: 10.1007/s13224-014-0663-8

50. Sreedharan M, Devadathan K, Kunju PAM, et al. Vitamin D Deficiency in Ambulant Children on Carbamazepine or Sodium Valproate Monotherapy. Indian Pediatr. 2018; 55(4):307-310. doi: 10.1007/s13312-018-1273-9

51. Agarwal N, Faridi MMA, Aggarwal A, Singh O. Vitamin D status of term exclusively breastfed infants and their mothers from India. Acta Paediatr. 2010; 99(11):1671-1674. doi:10.1111/j.1651-2227.2010.01912.x

52. Mathur NB, Saini A, Mishra TK. Assessment of adequacy of supplementation of Vitamin D in very low birth weight preterm neonates: A randomized controlled trial. J Trop Pediatr. 2016; 62(6):429-435. doi:10.1093/tropej/fmv110

53. Kumar GT, Sachdev HS, Chellani H, Rehman AM, Singh V, Arora H, Filteau S. Effect of weekly Vitamin D supplements on mortality, morbidity, and growth of low birthweight term infants in India up to age 6 months: randomised controlled trial. Bmj. 2011; 342: d2975. doi:10.1136/bmj.d2975

54. Marwaha RK, Tandon N, Chopra S, et al. Vitamin D status in pregnant Indian women across trimesters and different seasons and its correlation with neonatal serum 25-hydroxyVitamin D levels. Br J Nutr. 2011; 106(9):1383-1389. doi: 10.1017/S000711451100170X

55. Agrawal A, Gupta A, Shrivastava J. Role of Vitamin-D Deficiency in Term Neonates with Late-Onset Sepsis: A Case-Control Study. J Trop Pediatr. 2019; 65(6):609-616. doi:10.1093/tropej/fmz021

56. Shukla K, Sharma S, Gupta A, Raizada A. Current Scenario of Prevalence of Vitamin D Deficiency in Ostensibly Healthy Indian Population: A Hospital Based Retrospective Study. Indian J Clin Biochem. 2016; 31(4):452-457. doi: 10.1007/s12291-016-0552-2

57. Schulze KJ, Christian P, Wu LS-F, et al. Micronutrient Deficiencies Are Common in 6- to 8-Year-Old Children of Rural Nepal, with Prevalence Estimates Modestly Affected by Inflammation. J Nutr. 2014; 144(6):979-987. doi:10.3945/jn.114.192336

58. Haugen J, Ulak M, Chandyo RK, Henjum S, Thorne-Lyman AL, Ueland PM, Midtun $\varnothing$, Shrestha PS, Strand TA. Low prevalence of Vitamin D insufficiency among Nepalese infants despite high prevalence of Vitamin D insufficiency among their mothers. Nutrients. 2016 Dec; 8(12):825. doi: $10.3390 /$ nu8120825

59. Avagyan D, Neupane SP, Gundersen TE, Madar AA. Vitamin D status in pre-school children in rural Nepal. Public Health Nutr. 2016; 19(3):470476. doi: 10.1017/S136898001500083X

60. Marasinghe E, Chackrewarthy S, Abeysena C, Rajindrajith S. Micronutrient status and its relationship with nutritional status in preschool children in urban Sri Lanka. Asia Pac J Clin Nutr. 2015; 24(1):144-151. doi:10.6133/apjcn.2015.24.1.17 
61. Hettiarachchi M, Liyanage C. Coexisting micronutrient deficiencies among Sri Lankan pre-school children: A community-based study. Matern Child Nutr. 2012; 8(2):259-266. doi:10.1111/j.1740-8709.2010.00290.x

62. Hettiarachchi M, Lekamwasam S, Liyanage C. Bone mineral density and nutritional status of healthy Sri Lankan preschool children. Int J Endocrinol Metab. 2011; 9(2):335-340. doi:10.5812/kowsar.1726913x.2385

63. Anwar S, Iqbal MP, Azam I, et al. Urban and rural comparison of Vitamin D status in Pakistani pregnant women and neonates. J Obstet Gynaecol. 2016; 36(3):318-323. doi:10.3109/01443615.2015.1050647.

64. Karim SA, Nusrat U, Aziz S. Vitamin D deficiency in pregnant women and their new borns as seen at a tertiary-care center in Karachi, Pakistan. Int J Gynecol Obstet. 2011; 112(1):59-62. doi: 10.1016/j.ijgo.2010.07.034

65. Ahmed AS, Ahmed T, Long KZ, et al. Prevalence and risk factors of Vitamin D insufficiency and deficiency among 6-24-month-old underweight and normal-weight children living in an urban slum of Bangladesh. Public Health Nutr. 2017; 20(10):1718-1728. doi: 10.1017/S1368980015003353.

66. Manaseki-Holland S, Mughal MZ, Bhutta Z, Shams MQ. Vitamin D status of socioeconomically deprived children in Kabul, Afghanistan. Int J Vitam Nutr Res. 2008; 78(1):16-20. doi:10.1024/0300-9831.78.1.16.

67. Mogire RM, Mutua A, Kimita W, Kamau A, Bejon P, Pettifor JM, Adeyemo A, Williams TN, Atkinson SH. Prevalence of vitamin D deficiency in Africa: a systematic review and meta-analysis. Lancet Glob Health. 2020; 8(1): e134-42.doi: 10.1016/S2214-109X(19)30457-7

68. World Health Organisation (WHO) [Internet] Levels and trends in child malnutrition worldwide. Available from:

<https://www.who.int/nutgrowthdb/jme_brochoure2017.pdf>

69. Kumar KM. Incidence trends for childhood type 1 diabetes in India. Indian J Endocrinol Metab.2015 (Suppl 1): S34. doi: 10.4103/22308210.155378.

70 Rahman S, Islam MT, Alam DS. Obesity and overweight in Bangladeshi children and adolescents: a scoping review. BMC Public Health. 2014; 14(1):1-8. doi: 10.1186/1471-2458-14-70.

71 World Health Organisation (WHO) [Internet] Momentum on Child TB: South East Asia (SEA). Available from: <https://www.who.int/tb/areas-ofwork/children/highlights_SouthEastAsia.pdf?ua=1>

72. Mavridou A, Pappa O, Papatzitze O, et al. Exotic tourist destinations and transmission of infections by swimming pools and hotsprings - A literature review [map]. Int J Environ Res Public Health. 2018; 15(12). doi: 10.3390/ijerph15122730.

73. Pereira-Santos M, Santos JY, Carvalho GQ, Santos DB, Oliveira AM. Epidemiology of vitamin D insufficiency and deficiency in a population in a sunny country: Geospatial meta-analysis in Brazil. Crit Rev Food Sci Nutr. 2019;59(13):2102-9. doi: 10.1080/10408398.2018.1437711

74. Badawi A, Arora P, Sadoun E, Al-Thani AA, Al Thani MH. Prevalence of vitamin D insufficiency in Qatar: a systematic review. J Public Health Res. 2012;1(3):229. doi: 10.4081/jphr.2012.e36

75. Siddiqee $\mathrm{MH}$, Bhattacharjee B, Siddiqi UR, Rahman MM. High prevalence of vitamin D insufficiency among South Asian pregnant women: $\mathrm{A}$ systematic review and meta-analysis. Br J Nutr. Forthcoming 2021. doi: 10.21203/rs.3.rs-328883/v1

76. Shams S. Why wearing the burqa is on the rise in South Asia? DW. 2016 Aug 24; World (Asia). Accessed December 30, 2020.

https://www.dw.com/en/why-wearing-the-burqa-is-on-the-rise-in-south-asia/a-19497638

77. UNICEF [Internet] South Asia. Adolescent and women's nutrition. Available from: <https://www.unicef.org/rosa/what-we-do/nutrition/adolescentand-womens-nutrition> Accessed December 2, 2020.

78. UNICEF [Internet] South Asia. Gender equality. Available from: <https://www.unicef.org/rosa/what-we-do/gender-equality> Accessed December 2, 2020.

79. Afifi L, Saeed L, Pasch LA, Huddleston HG, Cedars MI, Zane LT, Shinkai K. Association of ethnicity, Fitzpatrick skin type, and hirsutism: a retrospective cross-sectional study of women with polycystic ovarian syndrome. Int J Womens Dermatol. 2017; 3(1):37-43. doi: 10.1016/j.jijwd.2017.01.006.

80. Cashman KD, Dowling KG, Škrabáková Z, et al. Vitamin D deficiency in Europe: Pandemic? Am JClinNutr. 2016; 103(4):1033-1044. doi:10.3945/ajcn.115.12087

81. Benskin LL. A Basic Review of the Preliminary Evidence That COVID-19 Risk and Severity Is Increased in Vitamin D Deficiency. Front Public Health. 2020; 8:513. doi: 10.3389/fpubh.2020.00513. 
82. Khadilkar A, Khadilkar V, Chinnappa J, Rathi N, Khadgawat R, Balasubramanian S et al. Prevention and treatment of vitamin D and calcium deficiency in children and adolescents: Indian Academy of Pediatrics (IAP) Guidelines. Indian pediatrics. 2017; 54(7): 567-73.doi: 10.1007/s13312-0171070-x.

83. Bouillon R. Comparative analysis of nutritional guidelines for vitamin D. Nat Rev Endocrinol. 2017; 13(8):466. doi: 10.1038/nrendo.2017.

84. Cavelaars, A. E. et al. Nutri-RecQuest: a web-based search engine on current micronutrient recommendations. Eur J Clin Nutr. 64 (Suppl. 2) S43S47 (2010). doi: 10.1038/ejcn.2010.60.

85. Aguiar M, Andronis L, Pallan M, Högler W, Frew E. Preventing vitamin D deficiency (VDD): A systematic review of Economic evaluations. Eur J Public Health. 2017; 27(2):292-301. doi: 10.1093/eurpub/ckw270

86. Arora HA, Dixit VI, Srivastava NI. Evaluation of knowledge, practices of vitamin D and attitude toward sunlight among Indian students. Asian Journal of Pharmaceutical and Clinical Research. 2016; 9(1):308.

87. Tariq A, Khan SR, Basharat A. Assessment of knowledge, attitudes and practice towards Vitamin D among university students in Pakistan. BMC Public Health. 2020; 20(1):1-0. doi: 10.1186/s12889-020-8453-y

88. World Health Organisation (WHO) [Internet] Adolescence: a period needing special attention. Available from: <https://apps.who.int/adolescent/second-decade/section2/page1/recognizingadolescence.html>Accessed June 2, 2021.

\section{Tables}

Table 1: Characteristics of selected study articles 


\begin{tabular}{|c|c|c|c|c|c|c|c|c|c|c|c|}
\hline Authors & Year & Country & $\begin{array}{l}\text { Study } \\
\text { Area } \\
\text { (Urban } \\
\text { or } \\
\text { Rural) }\end{array}$ & $\begin{array}{l}\text { Study } \\
\text { design }\end{array}$ & Age & Gender & $\begin{array}{l}\text { Socio } \\
\text { economic } \\
\text { status }\end{array}$ & $\begin{array}{l}\text { Vitamin D } \\
\text { estimation } \\
\text { method }\end{array}$ & $\begin{array}{l}\text { Sample } \\
\text { size (N) }\end{array}$ & $\begin{array}{l}\text { Average } \\
\text { level of } \\
\text { vitamin } \\
\text { D } \\
\text { (ng } \\
\text { /mL) }\end{array}$ & $\begin{array}{l}\text { Standard } \\
\text { deviation } \\
\text { (S.D.) }\end{array}$ \\
\hline $\begin{array}{l}\text { Marwaha et } \\
\text { al [26] }\end{array}$ & 2005 & India & Urban & $\begin{array}{l}\text { Community } \\
\text { - CS }\end{array}$ & $\begin{array}{l}10-18 \\
y\end{array}$ & Both & Both & RIA & 5137 & 11.8 & 7.2 \\
\hline $\begin{array}{l}\text { Sahu et al } \\
\text { [27] }\end{array}$ & 2008 & India & Rural & $\begin{array}{l}\text { Community } \\
\text { - CS }\end{array}$ & $\begin{array}{l}10-20 \\
y\end{array}$ & Both & Lower & RIA & 155 & 20.16 & 9 \\
\hline $\begin{array}{l}\text { Mandlik et } \\
\text { al [28] }\end{array}$ & 2018 & India & Rural & $\begin{array}{l}\text { Community } \\
\text { - CS }\end{array}$ & $6-12 y$ & Both & NM & ELISA & 359 & 23.4 & 4.12 \\
\hline $\begin{array}{l}\text { Kapil et } \\
\text { al [29] }\end{array}$ & 2017 & India & NM & $\begin{array}{l}\text { Community } \\
\text { - CS }\end{array}$ & $6-18 y$ & Both & Both & CLIA & 626 & 11.8 & 5.475 \\
\hline $\begin{array}{l}\text { Basu et } \\
\text { al [30] * }\end{array}$ & 2014 & India & Both & $\begin{array}{l}\text { Hospital - } \\
\text { CS }\end{array}$ & $6-16 y$ & Both & NM & CLIA & 154 & 13.5 & 12.22 \\
\hline Puri et al [31] & 2007 & India & NM & $\begin{array}{l}\text { Community } \\
\text { - CS }\end{array}$ & $6-18 y$ & Girls & Both & RIA & 404 & 12.748 & 6.172 \\
\hline $\begin{array}{l}\text { Kadam et } \\
\text { al [32] }\end{array}$ & 2011 & India & NM & $\begin{array}{l}\text { Community } \\
\text { - CS }\end{array}$ & $8-12 y$ & Girls & Lower & RIA & 214 & 24.74 & 10.48 \\
\hline $\begin{array}{l}\text { Khadgawat } \\
\text { et al [33] }\end{array}$ & 2013 & India & NM & $\begin{array}{l}\text { Community } \\
\text { - RCT }\end{array}$ & $\begin{array}{l}10-14 \\
y\end{array}$ & Both & NM & CLIA & 713 & 11.69 & 5.36 \\
\hline $\begin{array}{l}\text { Chaudhuri et } \\
\text { al [34] }\end{array}$ & 2016 & India & NM & $\begin{array}{l}\text { Hospital - } \\
\text { CC }\end{array}$ & $8-18 y$ & Both & NM & CMIA & 50 & 22.5 & NM \\
\hline $\begin{array}{l}\text { Sharawat et } \\
\text { al [35] }\end{array}$ & 2019 & India & Rural & $\begin{array}{l}\text { Community } \\
\text { - CS }\end{array}$ & $5-10 y$ & Both & Lower & IRMA & 100 & 17.652 & 9.912 \\
\hline $\begin{array}{l}\text { Marwaha et } \\
\text { al [36] }\end{array}$ & 2015 & India & NM & $\begin{array}{l}\text { Community } \\
\text { - CS }\end{array}$ & $\begin{array}{l}10-15 \\
y\end{array}$ & Both & NM & CLIA & 205 & 6.3 & 4.6 \\
\hline $\begin{array}{l}\text { Sarma et } \\
\text { al [37] }\end{array}$ & 2019 & India & Both & $\begin{array}{l}\text { Community } \\
\text { - CS }\end{array}$ & $8-14 y$ & Both & NM & RIA & 500 & 37.7 & 0.93 \\
\hline $\begin{array}{l}\text { Sanwalka et } \\
\text { al [38] }\end{array}$ & 2012 & India & NM & $\begin{array}{l}\text { Community } \\
\text { - CS }\end{array}$ & $\begin{array}{l}15-18 \\
y\end{array}$ & Girls & NM & RIA & 120 & 8.88 & 4.384 \\
\hline $\begin{array}{l}\text { Mandlik et } \\
\text { al [39] }\end{array}$ & 2017 & India & Rural & $\begin{array}{l}\text { Community } \\
\text { - RCT }\end{array}$ & $6-12 y$ & Both & NM & ELISA & 106 & 23.84 & 4.44 \\
\hline $\begin{array}{l}\text { Borker et } \\
\text { al [40] }\end{array}$ & 2009 & India & NM & $\begin{array}{l}\text { Hospital - } \\
\text { CC }\end{array}$ & $6-12 y$ & Both & NM & HPLC & 50 & 26.16 & 12.28 \\
\hline $\begin{array}{l}\text { Garg et } \\
\text { al [41] }\end{array}$ & 2013 & India & Urban & $\begin{array}{l}\text { Community } \\
\text { - CS }\end{array}$ & $\begin{array}{l}\text { Mean } \\
\text { age } 14 \\
y\end{array}$ & Both & NM & RIA & 1829 & 8.3 & 5.2 \\
\hline $\begin{array}{l}\text { Khadilkar et } \\
\text { al [42] }\end{array}$ & 2012 & India & NM & $\begin{array}{l}\text { Community } \\
\text { - CS }\end{array}$ & $8-12 y$ & Girls & Lower & RIA & 214 & 24.73 & 10.65 \\
\hline $\begin{array}{l}\text { Patel et } \\
\text { al [43] }\end{array}$ & 2015 & India & NM & $\begin{array}{l}\text { Community } \\
\text { - CS }\end{array}$ & $\begin{array}{l}10-14 \\
y\end{array}$ & Both & Both & CMIA & 181 & 17.7 & 6.7 \\
\hline $\begin{array}{l}\text { Marwaha et } \\
\text { al [44] }\end{array}$ & 2017 & India & NM & $\begin{array}{l}\text { Community } \\
\text { - CS }\end{array}$ & $6-18 y$ & Girls & NM & CLIA & 847 & 9.9 & 5.6 \\
\hline $\begin{array}{l}\text { Prasad et al } \\
\text { [45] }\end{array}$ & 2016 & India & NM & $\begin{array}{l}\text { Hospital - } \\
\text { CC }\end{array}$ & $<3 y$ & Both & NM & ELISA & 61 & 31 & 8.7 \\
\hline $\begin{array}{l}\text { Agarwal et } \\
\text { al [46] }\end{array}$ & 2012 & India & NM & $\begin{array}{l}\text { Hospital - } \\
\text { CS }\end{array}$ & NM & Both & NM & RIA & 336 & 6.15 & NM \\
\hline $\begin{array}{l}\text { Basu et al } \\
{[30] \text { * }}\end{array}$ & 2014 & India & Both & $\begin{array}{l}\text { Hospital - } \\
\text { CS }\end{array}$ & $1-5 y$ & Both & Lower & CLIA & 156 & 23 & 16.29 \\
\hline $\begin{array}{l}\text { Wayse et al } \\
\text { [47] }\end{array}$ & 2003 & India & NM & $\begin{array}{l}\text { Hospital - } \\
\text { CC }\end{array}$ & $\begin{array}{l}2 m-5 \\
y\end{array}$ & Both & Middle & RIA & 70 & 15.36 & NM \\
\hline $\begin{array}{l}\text { Filteau et al } \\
\text { [48] }\end{array}$ & 2015 & India & NM & $\begin{array}{l}\text { Community } \\
\text { - CS }\end{array}$ & $\begin{array}{l}\text { Mean } \\
\text { age } 5 \text { y }\end{array}$ & Both & Lower & RIA & 902 & 13.08 & 9.2 \\
\hline Taru et al & 2015 & India & NM & Hospital - & NM & Both & NM & NM & 50 & 7.25 & 6.29 \\
\hline
\end{tabular}




\begin{tabular}{|c|c|c|c|c|c|c|c|c|c|c|c|}
\hline $\begin{array}{l}\text { Sreedharan } \\
\text { et al [50] }\end{array}$ & 2018 & India & NM & $\begin{array}{l}\text { Hospital - } \\
\text { CC }\end{array}$ & $2-13 y$ & Both & NM & ELISA & 109 & 30.1 & 23.42 \\
\hline $\begin{array}{l}\text { Agarwal et al } \\
\text { [51] }\end{array}$ & 2010 & India & Urban & $\begin{array}{l}\text { Hospital - } \\
\text { CS }\end{array}$ & $\begin{array}{l}10 \\
\text { weeks }\end{array}$ & Both & Lower & RIA & 97 & 10.47 & 6.74 \\
\hline $\begin{array}{l}\text { Mathur et al } \\
\text { [52] }\end{array}$ & 2016 & India & NM & $\begin{array}{l}\text { Hospital - } \\
\text { RCT }\end{array}$ & NM & Both & NM & ECLIA & 50 & 12.65 & 10 \\
\hline $\begin{array}{l}\text { Kumar et al } \\
\text { [53] }\end{array}$ & 2011 & India & NM & $\begin{array}{l}\text { Hospital - } \\
\text { RCT }\end{array}$ & $\begin{array}{l}6 \\
\text { months }\end{array}$ & Both & NM & RIA & 237 & 14.4 & 10.2 \\
\hline $\begin{array}{l}\text { Marwaha et } \\
\text { al [54] }\end{array}$ & 2011 & India & NM & $\begin{array}{l}\text { Hospital - } \\
\text { CS }\end{array}$ & $\begin{array}{l}6 \\
\text { weeks }\end{array}$ & Both & Lower & RIA & 342 & 8.92 & 4.2 \\
\hline $\begin{array}{l}\text { Agrawal et } \\
\text { al [55] }\end{array}$ & 2019 & India & Both & $\begin{array}{l}\text { Hospital - } \\
\text { CC }\end{array}$ & $\begin{array}{l}3 d-21 \\
d\end{array}$ & Both & NM & CLIA & 50 & 14.88 & 7.2 \\
\hline $\begin{array}{l}\text { Shukla et al } \\
\text { [56] }\end{array}$ & 2016 & India & NM & $\begin{array}{l}\text { Hospital - } \\
\text { CS }\end{array}$ & $<20 y$ & Both & NM & ECLIA & 73 & 14.115 & 7.725 \\
\hline $\begin{array}{l}\text { Schulze et al } \\
\text { [57] }\end{array}$ & 2014 & Nepal & Rural & $\begin{array}{l}\text { Community } \\
\text { - RCT }\end{array}$ & $6-8 y$ & Both & NM & $\mathrm{CIA}$ & 1000 & 26.52 & 7.4 \\
\hline $\begin{array}{l}\text { Haugen et } \\
\text { al [58] }\end{array}$ & 2016 & Nepal & Urban & $\begin{array}{l}\text { Community } \\
\text { - CS }\end{array}$ & $\begin{array}{l}1-12 \\
m\end{array}$ & Both & NM & LCMS & 466 & 32.8 & 8.56 \\
\hline $\begin{array}{l}\text { Avagyan et } \\
\text { al [59] }\end{array}$ & 2015 & Nepal & Rural & $\begin{array}{l}\text { Community } \\
\text { - CS }\end{array}$ & $1 y-5 y$ & Both & NM & LCMS & 280 & 12.6 & 4.8 \\
\hline $\begin{array}{l}\text { Marasinghe } \\
\text { et al [60] }\end{array}$ & 2015 & Sri Lanka & Urban & $\begin{array}{l}\text { Community } \\
\text { - CS }\end{array}$ & $2-5 y$ & Both & NM & CLIA & 340 & 23.5 & 8.97 \\
\hline $\begin{array}{l}\text { Hettiarachchi } \\
\text { et al [61] }\end{array}$ & 2010 & Sri Lanka & NM & $\begin{array}{l}\text { Hospital - } \\
\text { CS }\end{array}$ & $3-5 y$ & Both & NM & IRMA & 248 & 33.71 & 14.1 \\
\hline $\begin{array}{l}\text { Hettiarachchi } \\
\text { et al [62] }\end{array}$ & 2011 & Sri Lanka & NM & $\begin{array}{l}\text { Hospital - } \\
\text { CS }\end{array}$ & $3-5 y$ & Both & NM & IRMA & 105 & 24.78 & 0.66 \\
\hline $\begin{array}{l}\text { Anwar et al } \\
\text { [63] }\end{array}$ & 2015 & Pakistan & Both & $\begin{array}{l}\text { Community } \\
\text { - CS }\end{array}$ & NM & Both & Lower & CLIA & 227 & 9.884 & 7.334 \\
\hline $\begin{array}{l}\text { Karim et al } \\
\text { [64] }\end{array}$ & 2010 & Pakistan & NM & $\begin{array}{l}\text { Hospital - } \\
\text { CS }\end{array}$ & NM & Both & Both & NM & 50 & 20.4 & 10.99 \\
\hline $\begin{array}{l}\text { Ahmed et } \\
\text { al [65] }\end{array}$ & 2015 & Bangladesh & Urban & $\begin{array}{l}\text { Community } \\
\text { - CS }\end{array}$ & $\begin{array}{l}0.5-2 \\
y\end{array}$ & Both & Both & EIA & 913 & 21.86 & 16.67 \\
\hline $\begin{array}{l}\text { Holland et } \\
\text { al [66] }\end{array}$ & 2007 & Afghanistan & NM & $\begin{array}{l}\text { Community } \\
\text { - CS }\end{array}$ & $\begin{array}{l}0.5-5 \\
y\end{array}$ & Both & NM & HPLC & 107 & 5 & NM \\
\hline
\end{tabular}

* Belongs to a single study. This study was conducted on a population from two separate age groups (below-six years and above-six years) and therefore we segregated the sample size into two groups for our analysis.

\section{Abbreviations used in Table 1}

RCT $=$ Randomized Control Trial, CC = Case Control, CS = Cross Sectional, CIA = Commercial Immunoassay, RIA = Radio Immune assay, ELISA = Enzyme Linked Immune Sorbent Assay, CLIA = Chemiluminescence immunoassay, CMIA = Chemiluminescent micro particle immune assay, IRMA = Immunoradiometric immunoassay, HPLC = High performance liquid chromatography, LCMS = Liquid chromatography tandem mass spectroscopy, EIA = Enzyme Immunoassay, ECLIA = Electrochemiluminescence Immunoassay, NM = Not mention, $y=$ Year $m=$ Month, $d=d a y$

Table 2: Result in accordance to country. 


\begin{tabular}{|c|c|c|c|c|}
\hline Country & $\begin{array}{l}\text { Study } \\
\text { found }\end{array}$ & $\begin{array}{l}\text { Total } \\
\text { participants }\end{array}$ & $\begin{array}{l}\text { Weighted mean level of vitamin D (Weighted standard } \\
\text { deviation) }\end{array}$ & $\begin{array}{l}\text { Prevalence of } \\
\text { hypovitaminosis }\end{array}$ \\
\hline India [26-56] & 31 & 14497 & $13.40 \mathrm{ng} / \mathrm{mL}(6.61)$ & $64 \%$ [95\% Cl: $46 \%$ to $79 \%]$ \\
\hline Nepal [57-59] & 3 & 1746 & $25.96 \mathrm{ng} / \mathrm{mL}(7.29)$ & $35 \%$ [95\% Cl: $1 \%$ to $83 \%]$. \\
\hline $\begin{array}{l}\text { Sri Lanka }[60- \\
62]\end{array}$ & 3 & 693 & $27.34 \mathrm{ng} / \mathrm{mL}(9.54)$ & $25 \%$ [95\% Cl: $16 \%$ to $36 \%]$ \\
\hline $\begin{array}{l}\text { Pakistan [63- } \\
64]\end{array}$ & 2 & 277 & 11.78 ng/mL (7.99) & $94 \%$ [95\% Cl: $90 \%$ to $96 \%]$ \\
\hline $\begin{array}{l}\text { Afghanistan } \\
\text { [65] }\end{array}$ & 1 & 107 & $5 \mathrm{ng} / \mathrm{mL}^{*}$ & $96.2 \%$ [95\% Cl: $91 \%$ to $99 \%$ ] \\
\hline $\begin{array}{l}\text { Bangladesh } \\
\text { [66] }\end{array}$ & 1 & 913 & $21.86 \mathrm{ng} / \mathrm{mL}(16.67)$ & $35.48 \%$ [95\% Cl: $32 \%$ to $39 \%$ ] \\
\hline
\end{tabular}

* Standard deviation was not mentioned in this study.

Table 3: Result following gender.

\begin{tabular}{|c|c|c|c|c|}
\hline Gender & $\begin{array}{l}\text { Number of } \\
\text { studies }\end{array}$ & $\begin{array}{l}\text { Total } \\
\text { participants }\end{array}$ & $\begin{array}{l}\text { Range of average vitamin D level (Standard } \\
\text { deviation) }\end{array}$ & $\begin{array}{l}\text { Prevalence of } \\
\text { hypovitaminosis }\end{array}$ \\
\hline $\begin{array}{l}\text { Both [26-30, 33-37, 39-41, 43, } \\
45-66]\end{array}$ & 36 & 16434 & 5 to $34 \mathrm{ng} / \mathrm{mL}$ ( 1 to 23 ) & $58 \%$ [95\% Cl: $43 \%$ to $73 \%]$ \\
\hline $\begin{array}{l}\text { Female only }[31,32,38,42 \text {, } \\
44]\end{array}$ & 5 & 1799 & 9 to $25 \mathrm{ng} / \mathrm{mL}$ (4 to 11 ) & $76 \%$ [95\% $\mathrm{Cl}: 46 \%$ to $96 \%]$ \\
\hline
\end{tabular}

Table 4: Result following age.

\begin{tabular}{|c|c|c|c|c|c|}
\hline Age & Category & $\begin{array}{l}\text { Study } \\
\text { found }\end{array}$ & $\begin{array}{l}\text { Total } \\
\text { participants }\end{array}$ & $\begin{array}{l}\text { Range of average vitamin D level } \\
\text { (Standard deviation) }\end{array}$ & $\begin{array}{l}\text { Prevalence of } \\
\text { hypovitaminosis }\end{array}$ \\
\hline 1 month $[46,49,52,55,63,64]$ & Neonates & 6 & 763 & 6 to $20 \mathrm{ng} / \mathrm{mL}$ (4 to 11 ) & $\begin{array}{l}85 \%[95 \% \mathrm{Cl}: 76 \% \\
\text { to } 91 \%]\end{array}$ \\
\hline $\begin{array}{l}1 \text { month }-5 \text { years }[45,47,48,51 \text {, } \\
53,54,57-62,65,66]\end{array}$ & $\begin{array}{l}\text { Infants and } \\
\text { preschool children }\end{array}$ & 14 & 4324 & 5 to $34 \mathrm{ng} / \mathrm{mL}$ (1 to 17 ) & $\begin{array}{l}55 \%[95 \% \mathrm{Cl}: 35 \% \\
\text { to } 75 \%]\end{array}$ \\
\hline $6-18$ years $[26,28-34,36-44]$ & School children & 17 & 12709 & 6 to $26 \mathrm{ng} / \mathrm{mL}$ (1 to 17 ) & $\begin{array}{l}57 \%[95 \% \mathrm{Cl}: 33 \% \\
\text { to } 80 \%]\end{array}$ \\
\hline $2-20$ years $[27,35,50,56]$ & Others & 4 & 437 & 14 to $30 \mathrm{ng} / \mathrm{mL}$ (8 to 23 ) & $\begin{array}{l}57 \%[95 \% \mathrm{Cl}: 35 \% \\
\text { to } 77 \%]\end{array}$ \\
\hline
\end{tabular}

\section{Figures}



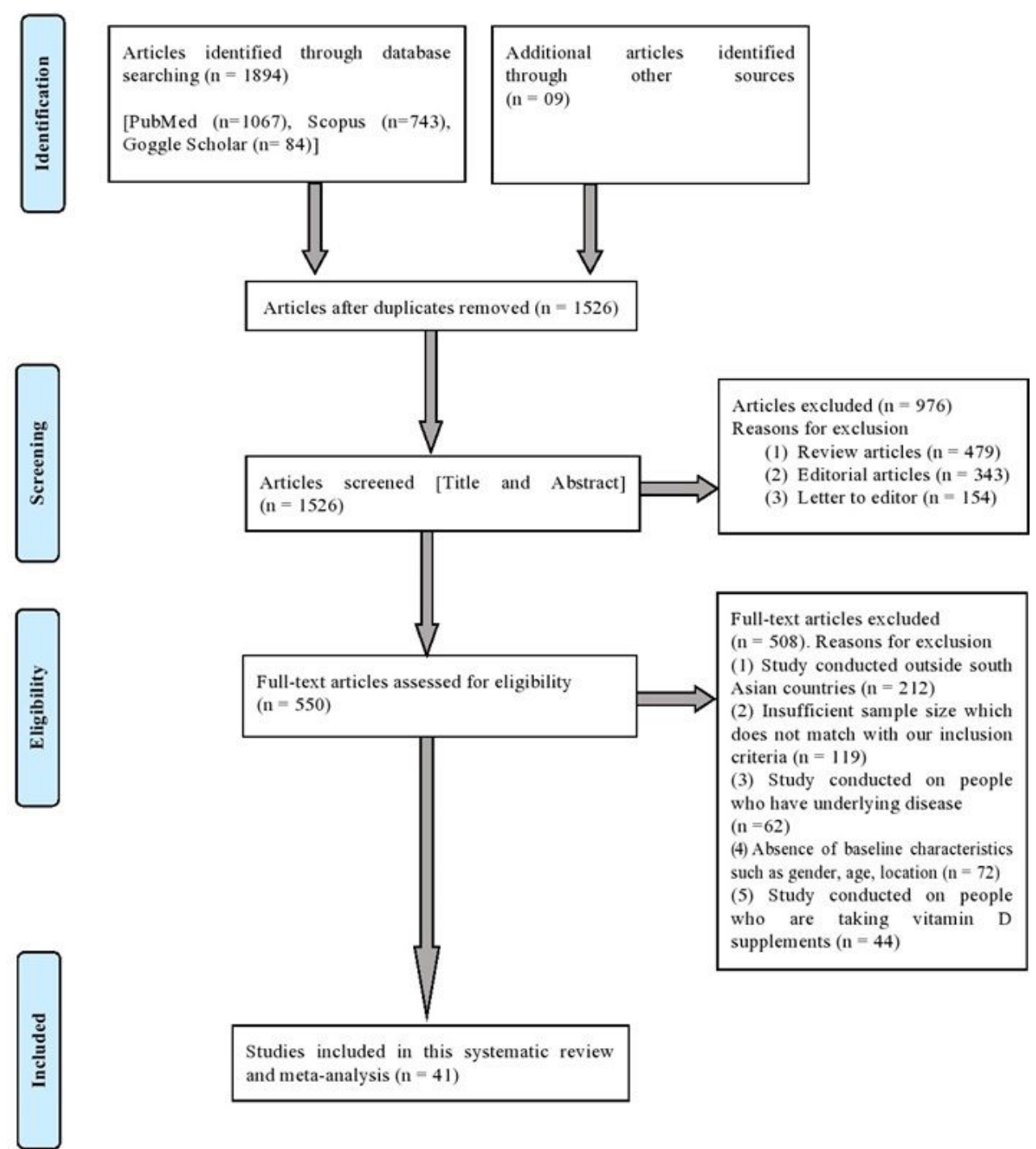

Studies included in this systematic review

and meta-analysis $(n=41)$

Figure 1

PRISMA chart showing the flow of information through the different phases of the systematic review. 


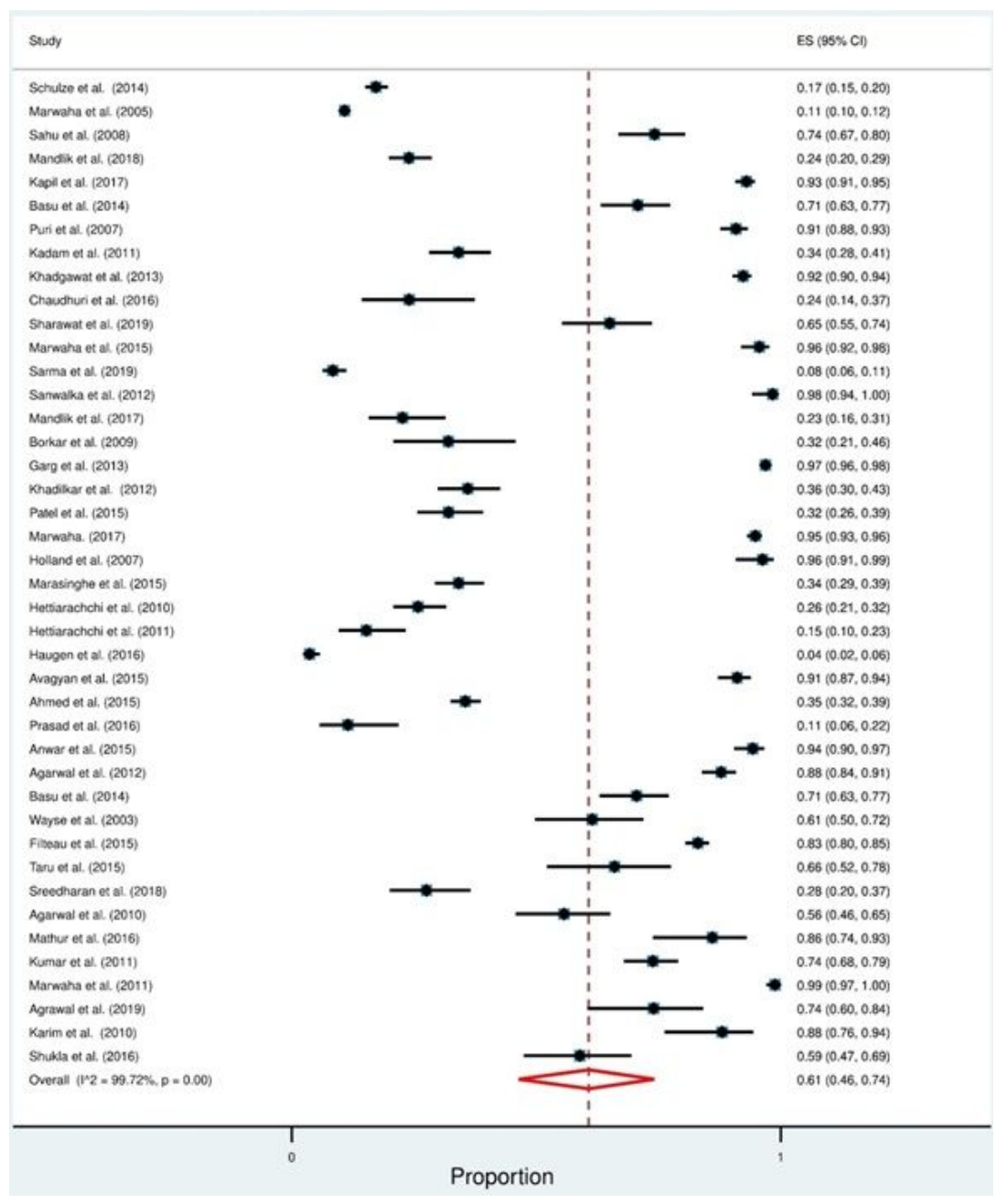

Figure 2

Forest plot displays the overall prevalence of hypovitaminosis D among South Asian children and adolescents. Each horizontal line of the forest plot represents an individual study and the box is plotted as prevalence for that study. Diamond at the bottom represents overall polled prevalence when all the individual studies are combined and averaged. The horizontal points of the diamond represent the limit of $95 \%$ confidence interval. 


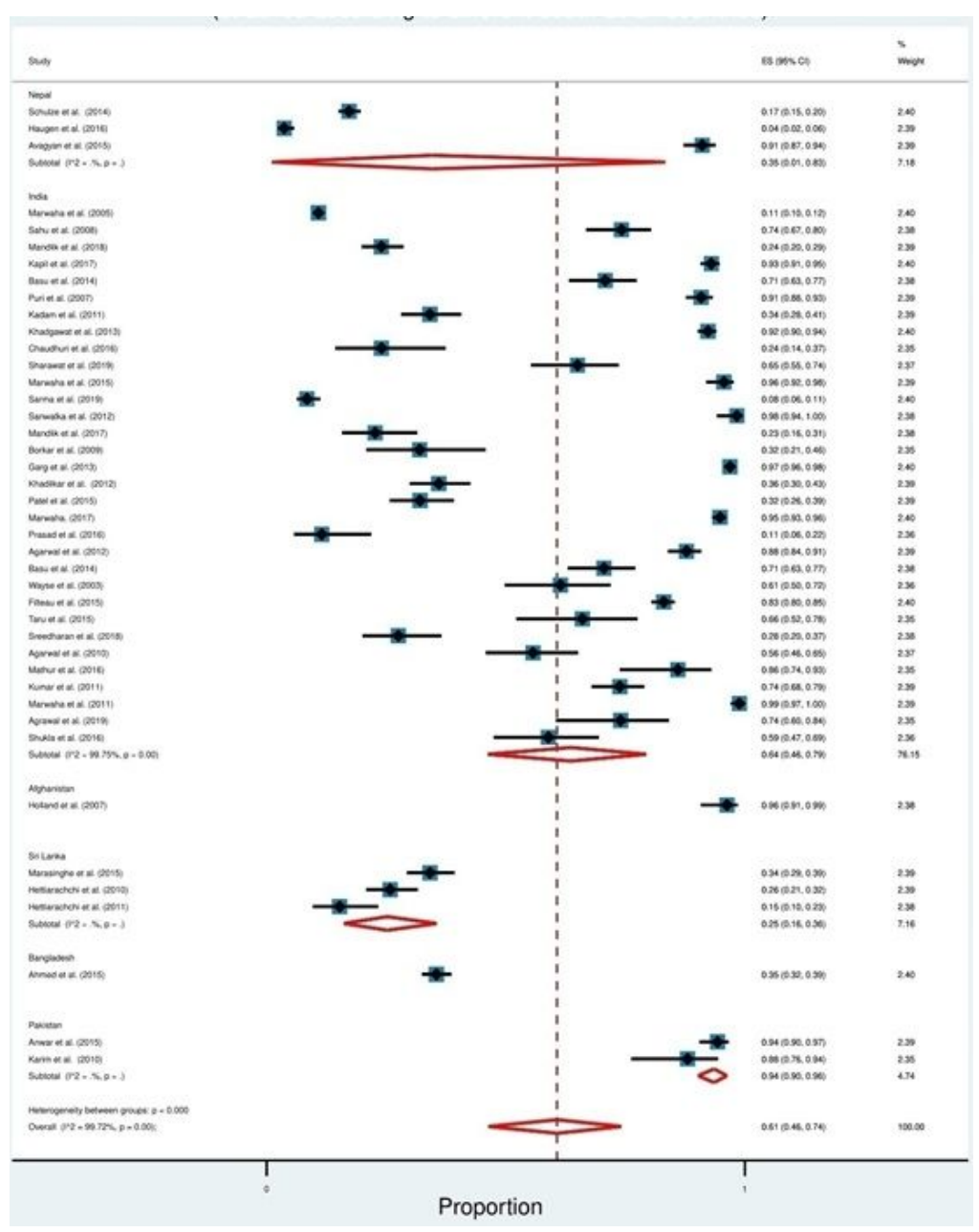

Figure 3

Forest plot displays the country-wise prevalence of hypovitaminosis D among South Asian children and adolescents. In this forest pot, all the diamonds, except the last one (overall pooled prevalence) represent polled prevalence for the individual country; (1) Nepal, (2) India, (3) Afghanistan, (4) Sri Lanka, (5) Bangladesh, (6) Pakistan. Each horizontal line of the forest plot represents an individual study and the box is plotted as prevalence for that study. The horizontal points of the diamond represent the limit of $95 \%$ confidence interval. 


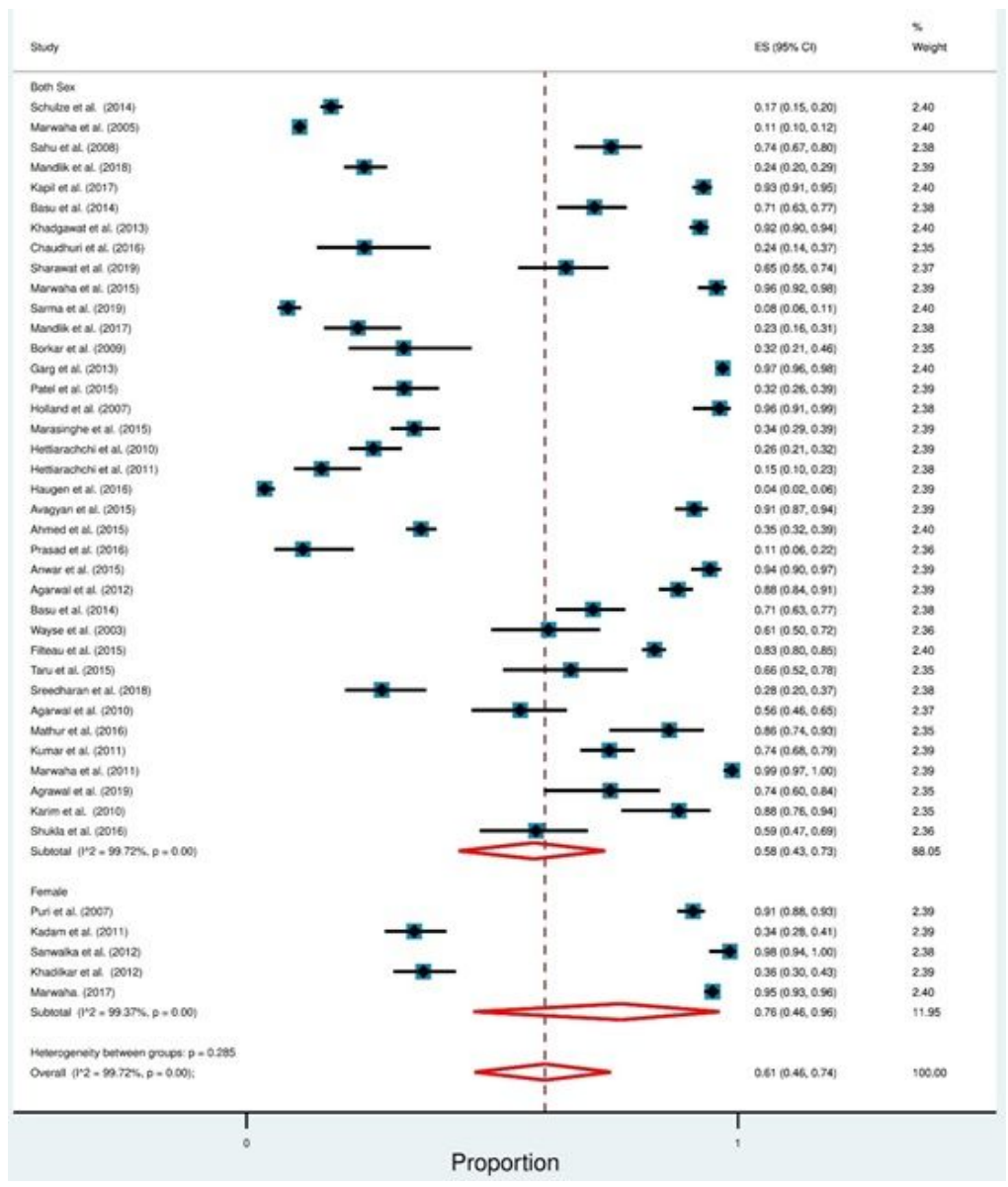

Figure 4

Forest plot following gender for the prevalence of hypovitaminosis D among South Asian children and adolescents. In this forest plot, all the diamonds except the last one (overall pooled prevalence) represent polled prevalence following gender. Here are two categories; studies that represent participants from both gender and the only female. Each horizontal line of the forest plot represents an individual study and the box is plotted as prevalence for that study. The horizontal points of the diamond represent the limit of $95 \%$ confidence interval. 


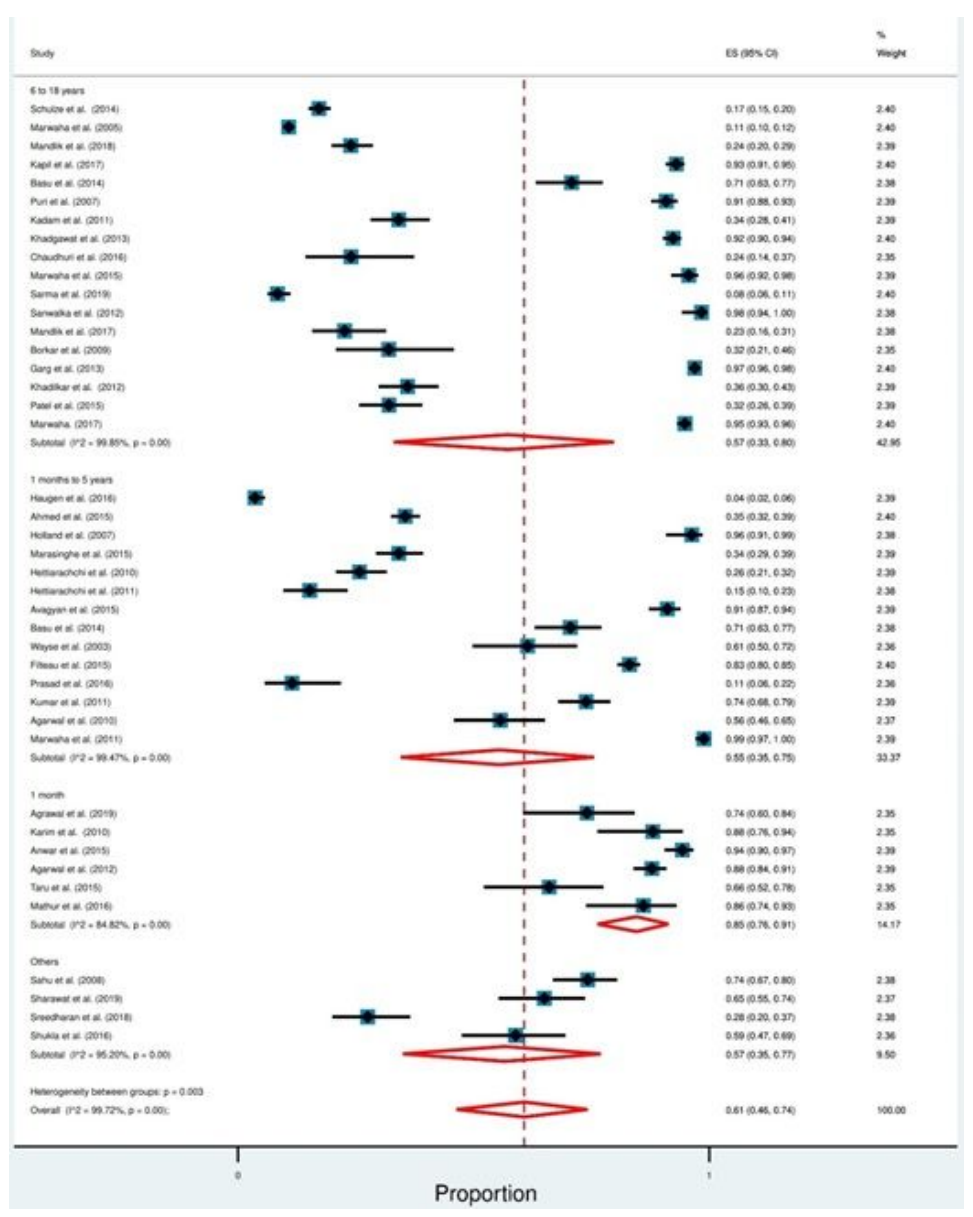

\section{Figure 5}

Forest plot following age for the prevalence of hypovitaminosis D among South Asian children and adolescents. In this forest plot, all the diamonds except the last one (overall pooled prevalence) represent polled prevalence following age. Here are four categories; studies; (1) 6-18 years of age (School) (2) < 5 years (Pre-School and Infants), (3) up to 1-month (Neonates), and (4) others. Each horizontal line of the forest plot represents an individual study and the box is plotted as prevalence for that study. The horizontal points of the diamond represent the limit of $95 \%$ confidence interval.

\section{Supplementary Files}

This is a list of supplementary files associated with this preprint. Click to download.

- Additionalfile.docx

- FigureS1.jpg

- Figures2.jpg 